\title{
Is There an Ideological Link Between Neopopulism and Neoliberalism?
}

\author{
Existe um link ideológico entre o \\ Neopopulismo e o Neoliberalismo?
}

VICTOR ARMONY*

RESUMO: Este artigo trata do ressurgimento do populismo na América Latina e, em particular, dos fundamentos ideológicos desse fenômeno. Inesperadamente, o populismo ressurgiu em vários países, como Argentina e Peru, na sequência de reformas neoliberais drásticas e abrangentes. Essa nova situação exige uma reinterpretação do fenômeno populista. $\mathrm{O}$ autor afirma que o neoliberalismo e o neopopulismo estabeleceram um forte elo no nível ideológico. Para fornecer evidências empíricas para essa hipótese, um corpus do discurso presidencial de Carlos Menem foi analisado. O autor conclui sugerindo que o próprio neoliberalismo tende a estimular tendências populistas na sociedade.

PALAVRAS-CHAVE: Populismo; neoliberalismo; economia política.

ABSTRACT: This paper deals with the resurgence of populism in Latin America, and particularly with the ideological underpinnings of this phenomenon. Quite unexpectedly, populism has reemerged in several countries, such as Argentina and Peru, in the wake of drastic and all-encompassing neoliberal reforms. This novel situation calls for a reinterpretation of the populist phenomenon. The author contends that neoliberalism and neopopulism have established a strong link at the ideological level. In order to provide empirical evidence for this hypothesis, a corpus of Carlos Menem's presidential discourse has been analyzed. The author concludes by suggesting that neoliberalism itself tends to stir up populist tendencies in society.

KEYWORDS: Populism; neoliberalismo; political economy.

JEL Classification: D72; Z13; E61.:

Populism is, undoubtedly, an enduring feature of Latin American politics. Even though populism has often been dismissed as either a "pathological" form of political behavior (based on irrational or false beliefs) or a Machiavellian device (that exploits those beliefs for an ulterior purpose), it certainly appears to be more than

\footnotetext{
* Department of Sociology of University of Quebec at Montreal, Montreal, Canada. E-mail: armony. victor@uqam.ca. Orcid https://orcid.org/0000-0002-5913-2417.
} 
a superficial or ephemeral phenomenon. Indeed, the recurrent pattern of the paternalistic leader - he "savior of the country" - who plays upon the masses seems to be embedded in Latin American public culture. One could actually contend that specific cultural values (e.g. the cult of manliness and personal loyalty, an organicist and naturalistic conception of nationality and social hierarchy, a fatalistic notion of history) favor the development of the populist bond with a (messianic or unscrupulous) leader who claims to represent the "common people", the "ordinary people", the "united people" or simply "our people". However, we have to be wary of culturalist explanations that put too much emphasis on "collective psychology" (i.e. "the populace in Latin America is prone to fall for strong leaders, emotional clichés and demagogic discourse"). In countries where the social structure is extremely unequal (in terms of income distribution, but also in terms of stratification by ethnicity, gender, and cultural background), where the polity is highly corrupt and openly clientelist, and where foreign control of key economic resources is coordinated by local elites, it is hardly surprising that populists succeed by "appealing) past the ossified institutions to the living person, proclaiming the vox populi unmediated" (Canovan, 1999: 14 ). Populism in Latin America has structural, as well as cultural roots.

Those who support the populist leader are not just passive and gullible individuals, fooled by empty rhetoric and calculatedly vague promises. We must assume that they have good reasons to make their choice ${ }^{1}$. This does not mean that images, symbols, and narratives do not play a key role in their political attitudes and behavior. Followers are mobilized against what they perceive as the guardians of the status $q u o^{2}$ the party system, the privileged minorities, the special interest groups, the ruling class etc. This perception is built on the grounds of specific representations of the national past, present, and future: What kind of country do we have? What kind of country can we have? What kind of country should we have? While required to produce short-term results, populist leaders also have to address these far-reaching questions in order to gain and uphold popular support (particularly when the short-term results do not seem to benefit the "ordinary" people). They have to put forward a plausible (though not necessarily realistic) project for the country's "take-off". Populism, in this sense, is typical of societies burdened by "unfinished aspirations" (Adelman, 1998). It is not a coincidence that populist leaders tend to emerge in "rich countries" (in terms of natural endowments, but also in terms of what is seen as an important national, cultural or ethnic heritage and destiny) with "poor peoples". As Canovan (1999: 12) puts it, "populism exploits this gap between promise and performance in democracy". The cases of Argentina,

\footnotetext{
1 "Dans l'action individuelle comme dans l'action collective, les acteurs sociaux mettent constamment en jeu des jugements de valeur. Je fais tel acte parce que je ('estime juste ou bon " (Boudon, 1998: 219-20).

${ }^{2}$ Di Tella refers, in his well-known definition of classic populism, to the "anti-status quo ideology" as a key element in the formation of a cross-class coalition (1965: 47).
} 
Brazil, Mexico, Peru, and Venezuela, all countries that are usually seen as having failed to achieve their full potential, come to mind.

This paper deals with the current resurgence of populism in Latin America, and particularly with the ideological underpinnings of this phenomenon. Quite unexpectedly, populism has reemerged in several countries, in the wake of drastic and all-encompassing neoliberal reforms. This novel situation calls for a reinterpretation of the populist phenomenon: Should we make a distinction between "old" and "new" populism? Which are the economic linkages between neopopulism and neoliberalism? Are they accidental, contingent, or necessary? Is this a specifically Latin American phenomenon, or can we draw parallels with North American and European populisms? Does populism represent a clear and present danger to democracy, or is it rather a "phase" in the process of political institutionalization? We will not, of course, tackle these issues here, although we will briefly touch on all of them. The focus of our discussion will be the following question: Is there an ideological nexus between neopopulism and neoliberalism? We will first put this question in context - sociologically and conceptually - in order to justify its relevance when trying to understand certain problematic aspects of the democratic transition in Latin America. We will then examine the case of Argentina's Carlos Menem. Specifically, we will analyze Menem's presidential discourse and, by comparing it with Raúl Alfonsín's, we will describe its neopopulist-neoliberal dimensions. In the third part of this paper, we will explore the ideological connections between neopopulist discourse and the neoliberal conceptions of society and the individual. We will conclude by suggesting that these links are significant, not only because leaders such as Menem take advantage of populist devices in order to gain popular consent for economic reforms, but also because neoliberalism itself tends to stir up populist tendencies in society.

\section{(NEO)POPULISM AND (NEO)LIBERALISM ${ }^{3}$}

The combination of neoliberalism and populism in Latin America has been described as an "unexpected convergence" (Weyland, 1999) and a "novel paradox" (Roberts, 1995), that is, a connection between two political options that would seem to be fundamentally at odds. While different hypothesis have been put forward to explain the political success of Menemism in Argentina and Fujimorism in Peru (the paradigmatic cases of "neoliberal populism"), they tend to coincide in two basic assumptions: (a1) the current forms of populism are to be distinguished from the "classic" ones (thus the term "neopopulism"); (b1) the populist component has to do especially with political strategy, while the neoliberal component concerns

\footnotetext{
${ }^{3}$ We will use the labels "[Neo]Populism" and "(Neo]Liberalism" in the following discussion to signify that even if a specific author uses the term "populism" or "liberalism" they are referring to their new forms.
} 
mostly the economic sphere (thus the distinction between "neopopulist politics" and "neoliberal economics", as in Weyland, 1996). Through these two assumptions, it becomes possible to explain away the obvious contradiction that exists between liberalism and populism: their "new" forms are not incompatible (as were their "classic" forms), and they operate in two separate, though interconnected, realms. Thus, neopopulism would no longer be characterized as essentially collectivist, corporatist, nationalist, and redistributionist, all aspects that are indeed extremely difficult to manage in a neoliberal setting. The neopopulist dimension appears then as a sort of "super structure" that facilitates the application and reduces societal resistance to costly market-oriented reforms.

We will argue that populism and liberalism are, in their "classic" forms, philosophically opposed. While liberalism, as an ideal-type, advocates the principle of a universalistic, elective and contractual bond between free and rational individuals, populism has usually been associated with a romantic, organic, naturalistic conception of the social order ${ }^{4}$. This opposition covers, of course, society as a whole. In other words, liberalism and populism, as paradigms, cannot be seen as mainly economic or political. They are mutually exclusive in their conception of nationality ("civic" versus "ethnic"), the State ("minimal" versus "maximal"), justice ("procedural fairness" versus "substantive good"), human agency ("free will" versus "social determinism"), social status ("achieved" versus "ascribed"), and so on. Although the historical forms of liberalism and populism have never been "pure", the distinction had remained quite clear until the recent emergence of a liberal-populist hybrid. This does not mean that liberalism cannot be circumscribed to economic matters in a given society. Free-market policies have been implemented in socially conservative, even dictatorial regimes (as in Chile). However, classic liberalism and populism as ideologies - that is, as systematic ways of understanding society as an object of experience and action ${ }^{5}$-are inherently incompatible. One cannot, for example, evoke the sacred national destiny and the indestructible union of the leader and the people in order to promote a competitive, open, and flexible labor market. On the other hand, neo-liberalism and neo-populism are not necessarily opposed. How can we explain this change?

Several scholars have already examined the seemingly incongruous mixture of political populism and economic liberalism that has taken place in certain Latin American countries during the 1990s. Analyzing the case of Fujimori in Peru, Kay

\footnotetext{
${ }^{4}$ This opposition holds even if we make a distinction between "authoritarian populism" and "democratic populism" (Dix, 1985). Democratic populism can be "modernizing" and more pragmatic in its programs of structural reform, but it remains strongly nationalistic and collectivist.

${ }^{5}$ We have in mind a definition of ideology such as the one proposed by Raymond Aron (1955: 246 ): "Les idéologies politiques mêlent toujours, avec plus ou moins de bonheur, des propositions de fait et des jugements de valeur. Elles exprimem une perspective sur le monde et une volonté tournée vers l'avenir. Elles ne tombent pas directement sur l'alternative vrai et du faux, elles n'appartiennent pas non plus à l'ordre du goût et des couleurs. La philosophie derniere et la hiérarchie des préférences appellent le dialogue plutôt que la preuve ou la réfutation”.
} 
suggests that the resurgence of populist politics in the neoliberal context should not be seen as an "historical aberration", but as a "political and economic strategy [...] carefully orchestrated from above" that aims at strengthening both the state and the market (1996: 90). In this view, the explanation of [neo]liberal [neo]populism is rather straightforward: in order to promote the economic agenda of the elites (i.e. market liberalization), presidential authoritarianism is used to weaken democratic institutions. Consequently, opposition parties and civil society organizations are not able to effectively challenge the economic policies, while the fragmented and impoverished masses pragmatically endorse "a president who is widely regarded as having brought Peru back from the brink of disaster" (Kay, 1996: 90-1). The idea that [neo] populism and [neo]liberalism can coexist, and even reinforce mutually, is also put forward by Knight in regard to Mexico: "Salinas showed [...] that a controlled economic populism was compatible with neoliberal economic" (1998: 246). Knight posits that the successful combination of [neo]populism and [neo]liberalism arises from the need of creating "a close bond between political leaders and led" (through personalist power, targeted social policies, and patronage) in times of economic upheaval and rapid mobilization. Knight views populism as a political style, rather than as a specific ideology or the result of a specific form of class alliance. In other words, [neo]populism is a phenomenon that can surface in very diverse situations, and one that can be combined with different types of economic and social policy. But this kind of perspective can lead, as Zermeño (1993) warns, to "essentialist" explanations: the masses vote for Fujimori or Salinas (or Menem) because they are spontaneously or naturally predisposed - because of a deeply entrenched political culture - to be seduced by the populist style, to the point of being duped and manipulated into accepting the "anti-popular" neoliberal reforms.

At this point, we have to raise several key questions: Is [neo]populism a mere package, a culturally acceptable wrapping, that is used by the elites to make their policies appear more enticing to the "common people"? And if so, is [neo]populism (as policy "form", or appearance, or means) necessary for [neo]liberalism (as policy "content", or substance, or goal) to be viable in Latin America? This question can, of course, be reversed: is [neo]liberalism necessary (as a pragmatic, opportunistic concession) for [neo]populist leaders to remain in power? The notion that [neo] populism is a style, or even a façade, does not necessary imply that this is prejudicial to democracy. Philip (1998), for example, argues that a temporary period of hyperpresidentialism during the early stages of market-oriented reform can be essential to avoid political outcomes that can threaten democratic stability. As he points out, "the key factor seems to be the ability of some individuals to enhance the powers already vested in the presidential institution" (Philip, 1998: 91). To do so, these individuals must be seen by the people as "sincere reformers" whose actions are a "genuine reflection of the popular will" (Philip, 1998: 91). Again, it would be a question of political "style", both as a means or method (strong, centralized presidentialism) and as an appearance. Figure 1 summarizes this kind of interpretation. 


\begin{tabular}{ll}
\hline \multicolumn{1}{c}{$\begin{array}{c}\text { [NEO)LIBERALISM CONTENT } \\
\text { (ECONOMIC GOALS) }\end{array}$} & \multicolumn{1}{c}{$\begin{array}{c}\text { [NEO]POPULISM } \\
\text { FORM (POLITICAL STYLE) }\end{array}$} \\
\hline - Privatization of public companies & MEANS: hyper-presidentialism \\
\cline { 2 - 2 } - Deregulation of national markets & $\begin{array}{l}\text { APPEARANCE: reflection of the popular will; } \\
\text { - Liberalization of international trade }\end{array}$ \\
\hline
\end{tabular}

This conception of the link between [neo]liberalism and [neo]populism in volves another set of assumptions: (a2) in general terms, the link is contingent ([neo] liberal goals could be pursued by non-populist means, and [neo]populist strategies could be used to further non-liberal projects), but it is likely to occur in certain situations where the prevailing political culture encourages populist pat terns; (62) both [neo]liberalism and [neo]populism are seen as mainly pragmatic and adaptive; this emphasizes the opportunistic and manipulative nature of both approaches. Assumptions a1 (distinction between "classic" and "new" phenomena) and a2 (contingent, more or less probable link) imply that neoliberalism and neopopulism are, to a great extent, free of normative constraints, while assumptions bl (separation of economic and political spheres) and b2 (pragmatism) entail a conception of social behavior and interactions as being primarily based on instrumental reasoning. In brief, most of the explanations that have been put forward in order to account for the new phenomenon tend to dismiss the ideological factor. In this view, those who promote (and profit from) neoliberal and neopopulist approaches, as well as those who support (or submit to) them, are seen to act in terms of either a rational maximization of gains, or an irrational and therefore erroneous perception and evaluation of reality. Simply put: either (1) people do not care about ideology; they vote for results; or (2) people are blinded by ideology; they vote for images, symbols, and illusions.

The first kind of hypothesis would explain why people vote rationally and consciously for a "stability" plan which is either beneficial for them or appears to be the least bad alternative. In this view, voters in Argentina do not really pay attention to Menem's discourse, they only care for what his government does. The second kind of hypothesis would explain why the lower-class citizens vote against their own interests: they are blinded by the president's rhetoric and continue to believe that Menem is a true Peronist and that what he does is actually for the good of the people and the country. In this second view, people are trapped in the same type of ideological device that held together the Peronist identity. But both hypotheses are too limited. On the one hand, to assert that people are completely oblivious to ideology means conceiving human beings as purely self-interested, cost-benefitcalculating agents who seek personal gain before anything else. It goes without saying that this view raises too many problems when applied to the sociological analysis of the ideational realm: people have good reasons to act in one way or another, but those reasons have to be culturally and subjectively meaningful to them. On the other hand, asserting that people are systematically duped by the 
official dogma, this in a context where there is, undeniably, an important degree of freedom of expression, means giving too much weight to the irrational component of social behavior. At the same time, we ought to admit that both explanations contain a grain of truth. Individuals are capable of rational assessment in terms of their own interests and opinions; but they are also receptive to inspiring images and emotional appeals. That is, we cannot begin to explain the success of the Menemist (or the Fujimorist) experience if we do not accept the possibility that the populist leader has successfully produced and conveyed a somewhat coherent and convincing discourse that addresses conceptions and beliefs deeply rooted in the collective mind. Even if Menem has stressed form over content, even if he has displayed a rather nonchalant attitude towards political language and rational debate, even if we acknowledge that possibly many Argentines have supported the government in a purely cynical and self-interested way, we have to accept nevertheless the fact that the state, as the key regulatory apparatus, has consistently promoted a given normative representation of the social order. This representation is not necessarily banal, untrue or inaccurate. By idealizing, demonizing, selectively remembering and forgetting things and events, it constitutes an ideological narrative. As Pocock (1984: 39) puts it, political discourse "is performative in the sense that it does things to people. It redefines them in their own perceptions, in those of others and by restructuring the conceptual universes in which they are perceived". That is why we will contend that neoliberalism and neopopulism have established a strong link at the ideological level. With the aim of providing empirical evidence for this hypothesis, we have analyzed Menem's presidential discourse.

\section{MENEM'S PRESIDENTIAL DISCOURSE}

In order to examine Carlos Menem's neopopulist rhetoric, we have used a database which we had compiled for a comprehensive analysis of the Argentine post authoritarian discourse (Armony, 2000). This database includes the complete transcription of 310 speeches delivered by Carlos Menem between 1989 and 1993, as well as 302 speeches delivered by Raúl Alfonsín between 1983 and 1989. The speeches were selected on the basis of several formal and empirical criteria in order to ensure the best possible sample of both presidential discourses. The statistical analysis of this database comprising more than a million words has allowed us to trace the key differences between the two presidents and, thus, to pinpoint the " populist component" of Menem's discourse (assuming, of course, that Alfonsín's discourse, used as the "control" corpus, is not fundamentally populist).

Figure 2 offers a snapshot of what differentiates Menem from Alfonsín in terms of key notions. The words shown have been selected through several computerized techniques: they characterize each speaker in terms of absolute and comparative frequencies (they are sorted by their quantitative importance). The goal of this procedure is to give a general idea of the distance between the two universes of meaning: 
the key notions retrieved in our corpus reflect the issues and themes that the speakers have consistently and distinctively emphasized during their respective terms in office ${ }^{6}$.

If we summarize the content of Alfonsín's discourse to the nation between 1983 and 1989, we see that he focuses on the need of an effort to be made by the entire society in order to solve the crisis and achieve democracy and modernization. To this end, he underscores the importance of rights and institutions in the transition from authoritarianism to a new form of peaceful coexistence (i.e. the core notion of convivencia). The examination of all sentences in our database that include Alfonsín's key notions has allowed us to single out certain "typical" formulas. For instance:

The fundamental responsibility of us all is to be protagonists of a new era. (6/28/1985).

We are all here facing the need of building a great Argentina $[\ldots]$ convinced as we are of the need of this effort [... ] It is, after all, together that we are going to make that Argentina that we want to leave to our children. $(1 / 17 / 1986)$

Figure 2: Alfonsín's and Menem's Key Notions

\begin{tabular}{|c|c|c|c|c|c|c|c|c|}
\hline \multicolumn{3}{|c|}{ Alfonsín's specific vocabulary } & \multicolumn{3}{|c|}{ Common vocabulary } & \multicolumn{3}{|c|}{ Menem's specific vocabulary } \\
\hline Words & FA & FM & Words & FA & FM & Words & FA & FM \\
\hline democracia & 27,2 & 7,7 & país & 48,2 & 35,4 & república & 5,1 & 21,8 \\
\hline sociedad & 16,6 & 5,7 & pueblo & 38,2 & 24,3 & hermanos & 1,2 & 12,2 \\
\hline esfuerzo & 18,2 & 6,9 & gobierno & 36,0 & 24.7 & hermanas & 0,1 & 8,4 \\
\hline modernización & 4,4 & 0,7 & argentinos & 31,7 & 22.7 & Argentina & 27,8 & 50,6 \\
\hline democrática & 4,2 & 0,9 & nación & 26,9 & 19,0 & Perón & 0,1 & 5,4 \\
\hline América Latina & 7,3 & 2,8 & polltica & 24,3 & 17,1 & quiero & 4,7 & 14,1 \\
\hline instituciones & 5,3 & 1,6 & anos & 23,5 & 15,5 & patria & 4,6 & 14,0 \\
\hline problemas & 10,7 & 5,2 & social & 22,5 & 14,3 & Dios & 1,3 & 7,3 \\
\hline transición & 2,5 & 0,2 & libertad & 21,6 & 15,6 & Estado & 9,5 & 20,9 \\
\hline superar & 4,4 & 1,3 & puede & 21,4 & 16,2 & comunidad & 3,1 & 9,8 \\
\hline derechos & 6,0 & 2,3 & tenemos & 21,2 & 16,1 & amigo & 0,1 & 3,2 \\
\hline convivencia & 3,8 & 1,0 & vamos & 20,5 & 15,5 & companeros & 0,1 & 3,0 \\
\hline necesidad & 7,2 & 3,2 & argentino & 20,3 & 12,7 & mercado & 2,4 & 7,5 \\
\hline encontrar & 3,3 & 0,8 & hacer & 19,6 & 13,1 & bendiga & 0.0 & 2,6 \\
\hline conjunto & 6,7 & 3,1 & vida & 18,6 & 14,3 & transformación & 2,0 & 6,7 \\
\hline soluciones & 4,2 & 1,4 & sistema & 16,4 & 11,9 & reitero & 0,5 & 3,6 \\
\hline crisis & 8,3 & 4,3 & pueblos & 15,5 & 11,8 & vengo & 0,4 & 3,4 \\
\hline democrático & 3,5 & 1,1 & justicia & 14,8 & 11,0 & corazón & 0,9 & 4,3 \\
\hline autoritarismo & 1,6 & 0,2 & economía & 14.7 & 9,1 & corrupción & 0,2 & 2,6 \\
\hline precios & 3,3 & 1,1 & Internacional & 14,6 & 10,6 & trabajo & 6,6 & 12,6 \\
\hline
\end{tabular}

\footnotetext{
${ }^{6}$ The relative frequencies are expressed as 1/10,000 occurrences in the respective samples. "FA": Frequency in Alfonsín's Discourse. "FM": Frequency in Menem's Discourse
} 
Contrary to Alfonsín, Menem puts himself at the center of his discourse: he is the one who summons the people "to set Argentina going" (poner en marcha). Carlos Menem addresses the "ordinary people" by appealing to their hearts and feelings of brotherhood and sisterhood. He mentions repeatedly the name of the country and uses the emotional term patria (fatherland), he calls upon God, Perón and the community. He urges his fellow countrymen to transform Argentina by fighting the corruption created by an overblown state which, Menem argues, not only prevents the market to function properly, but rewards vested interests instead of honest and hard work. It is no wonder, then, that Menem advocates a "capitalism that is no longer associated with the Welfare state". The state, in his view, "has a purpose as long as it is useful to the nation". To support an interventionist state is to validate and reproduce ideological conceptions that are "absurd", "static", "false", "sectarian", "capricious", "hollow", "blind". As the presidents puts it in an address to a meeting of philosophers:

We have a national doctrine, because we believe that the nation comes before any ideology, any partisan conception. The nation comes before the state. [...] The state only has a justification inasmuch as it serves the people and the society. (11/17/1989).

Menem invites his fellow citizens to an "epic that begins in the soul of each Argentine". Insisting on the need of " union among the Argentine brothers, civilians and military", the president portrays a "fraternal country" that is being salvaged from the "most deep decay". The goal is to see Argentina become "a nation that its people can be proud of". A typical sentence depicts a relationship where love and trust provide the social amalgam: "This president will always have his hand held out and his heart opened to say, 'Brother, let's keep on working for the greatness of our fatherland and for the happiness of its people"'. The vision for the new country is put forward by Menem in unambiguous terms: "Argentina is one of the greatest countries of the world, because of its spiritual grandeur and its economic development". The president contends that Argentina "deserves a future of happiness and glory", not "this situation of decline and stagnation", and that what he wants is to "change Argentina's gray, dark history", in order not to "miss the train of history". If we perform a collocation analysis ${ }^{7}$ of the term "Argentina" in Menem's discourse, we observe that the associated terms evoke an idealized, even romanticized, image of the country (Figure 3 ).

\footnotetext{
${ }^{7}$ The analysis of collocations is a procedure aiming to obtain, for a given term in a corpus, the list of highly correlated words. The correlation is measured in terms of statistically significant co-occurrence. When a word is consistently used in the same sentences where the term under analysis occurs, it can be said that the former is a "sentence collocate" of the latter. A statistical test compares the actual number of sentence collocations against the expected number of collocations which would occur if these collocations were random.
} 
- Change

- Cherished

- Fatherland

- Great

ARGENTINA

- Greatness

- Happy

- History

- New

- Transformation

- World

Let's point out that the term "world" emerges as a key element in Menem's discourse. Its use increases steadily during his presidency, along with a set of other words such as "millions", "dollars", "reform", and "resources", all of them connected to the issue of economic liberalization. The presidential discourse makes frequent references to the country's relative position in a changing international context: "some decades ago, we were one of the ten best countries in the world", then "we fell down to the hundredth rank in 1989", and now "Argentina is already among the best thirty countries". In 1993, the president was eager to announce that Argentina had become "the most powerful country in Latin America and in some parts of the world". The objective basis for these statements was, at best, precarious. But this is hardly a predicament for a president who affirmed that "we have succeeded in doing what others have not achieved in sixty years, not here, not anywhere in the world". This most challenging deed is, of course, Argentina's "insertion in the new international order". In this "new world being born", the "only border that remains is between the new and the old world". Menem emphasizes the importance of "working and producing efficiently," and the need of "becoming partners with the best" and, more precisely, with "the biggest power in the world which, obviously and thanks to God, is in this hemisphere". The following excerpts clearly show Menem's conception of what Argentina should become in the wake of globalization:

I want to tell you once again that Argentina and its people were born to succeed, they were born to win, they were born to become a great nation, a powerful state (12/9/1989).

National unity is the dynamic engine of the muscle which moves us to recuperate the lost and forgotten greatness of the nation. (5/1/1990)

Terms like "change", "transformation”, "new”, and "history" are repeatedly used to represent the turning point in the political and economic evolution of the country. It is not surprising that the presidential discourse systematically suggests 
the existence of a dichotomy between the Argentina of the future and the Argentina of the past. By using emotionally charged words, Menem simplifies the country's choices, and offers an overly optimistic perspective to his fellow citizens. Figure 4 shows a sample of the expressions used by the president.

Figure 4: Selected Adjectives Used by Menem to Characterize Argentina (translated terms)

\begin{tabular}{ll}
\hline \multicolumn{1}{c}{ Future } & \multicolumn{1}{c}{ The Past } \\
\hline a coherent Argentina & a chaotic Argentina \\
a glorious Argentina & a closed Argentina \\
a great Argentina & a decadent Argentina \\
a growing Argentina & a desintegrated Argentina \\
a powerful Argentina & a frustrating Argentina \\
a transcendent Argentina & a hypocrite Argentina \\
a truly capitalist Argentina & a sleeping Argentina \\
a vital Argentina & a suffering Argentina \\
an Argentina with a capital A & an isolated Argentina \\
\hline
\end{tabular}

The study of word frequencies can sometimes give us an insight into a speaker's worldview (Armony and Duchastel, 1995). By consistently using or avoiding certain terms, the speaker manifests a set of ingrained preferences. Obviously, this kind of analysis must be carried out on large amounts of data, in order to detect clear tendencies. A very interesting quantitative feature of Menem's discourse is the variation in the relative use of the two main markers of national identification: the terms "Argentina" (the country) and "Argentines" (the people). Figure 5 reveals a strikingly stable trend that can hardly be dismissed as the result of random fluctuations. With an almost geometrical configuration, the chart shows how the ratio between the two terms grows steadily from 1.6 in 1989 to 7.4 in 1993 . What is the meaning of this increasing use of the name of the country, correlated to a decreasing reference to its inhabitants? Although it is extremely difficult to provide a definite answer, we can make the assumption - given the overall nature of Menem's discourse - that the president is more and more focused on the idea of Argentina, this entity that has to realize its potential and find its proper place among the nations, than on the individual fate of the men and women who happen to be part of it. Thus, we could say, Argentina - its prominence, its glory - becomes an end in itself.

As Calhoun (1995) suggests, there are "three different but interrelated modes of claiming a broader political community, one outside the state apparatus": people, public, and nation. The nation refers to the "unity of the whole", the people to the "difference between rulers and ruled", while the public is the "differentiated citizenry" that constitutes the "proper referent of public discourse and the ground for 
Figure 5: Use of the Terms Argentina and Argentines in Me nem's Discourse (1 in 10,000 occurrences)

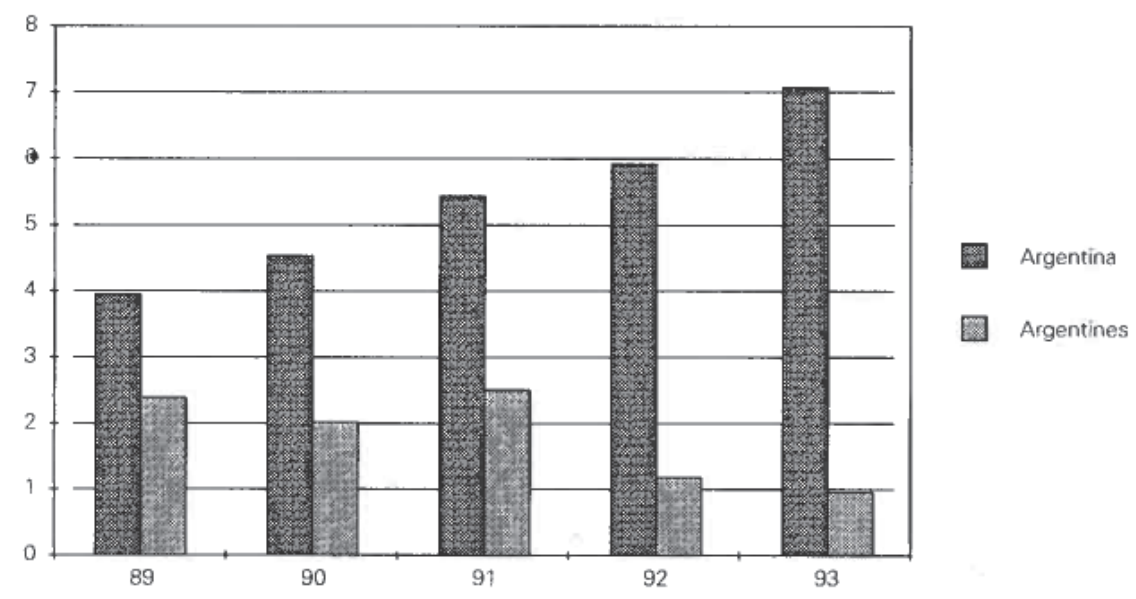

democratic claims of self-governance" (Calhoun, 1995: 240). It seems clear that the conception of the political community conveyed by Menem is mainly based on the representation of the putative "needs of the nation ", which go beyond "sectarian interests", "pusillanimous attitudes", or the complaints made by certain "privileged minorities". And the public itself - the citizenry formed by all Argentines - becomes a dwindling referent in Menem's discourse.

Let's sum up the fundamental differences between Alfonsín's and Menem's discourses. While Alfonsín portrayed a "pluralist society" to be built through collective will and cooperation, Menem has focused his discourse on the myth of a Great Argentina. This is of course typical of populist rhetoric: patriotic ardor, cohesive community, faith in destiny, etc. But as the results of the analysis suggest, Menem's discourse is not just a replication of Perón's. The demagogic style, the simplistic images, the vague promises are all there, but we also see the main themes of the neoliberal creed: unleash the market forces, trim down the welfare state, mistrust political debate, embrace pragmatism, hail globalization... One has to read hundreds of pages with Menem's speeches (as the author of this paper has done) to realize to what extent the president publicly, continuously and enthusiastically endorses the economic program of his government. In a remarkably crafty manner, Menem appeals to el pueblo to justify the liberalization of the economy:

Free market and an open economy have put an end to the impunity of fixing monopolist and oligopolist prices, which always end harming the humblest. In a truly popular - I insist: popular - market economy, businesses have to produce more, and not simply charge higher prices. (5/1/ 1991)

Political discourse in Argentina, be it from the left or the right, has always tended to posit a causal connection between the problems of national disunity and 
the fact that the country has not raised to the level it should "naturally" have: in this kind of explanation, a given group is to blame for not acting in concert with the rest of society towards the accomplishment of Argentina's "manifest destiny". But one can argue that the causal link between the two problems actually goes the other way around. The conservatives blamed the undisciplined immigrant, then the Peronists blamed the "oligarchy" and its associates, after that the military blamed the Peronists and later the "leftists". It is even possible to assert that political and social divisions in Argentina were not infrequently magnified ideologically in order to provide an account for the country's failure to attain the prominence to which many believe it was predestined. Otherwise, Argentines would have to face the fact that their country is not inherently important, and that in spite of its dreams of splendor and distinction, its fate has never been much different from that of other Third World nations. Menem's success in the ideological realm has been that of reviving the myth of a Great Argentina, by shifting the blame from one or other of the usual suspects, to what has become the great and sole culprit: the bureaucratic state. Suddenly, the whole civil society is victimized, Peronists and non-Peronists, the military and the social movements, the middle class and the working class. The recurring image of a divided country is again utilized, but this time the opposition is between the state and the nation.

How did the state use to grow? Simply by appealing to the socialquestion, something which in the end would disadvantage the majority of the Argentine people, and would create new social problems. (9/15/1992)

The main argument is that the state has continuously benefited some privileged minorities and thus handicapped Argentina's "natural" development. The successful control over inflation - which in fact created the illusion of a strong currency by pegging its value to the American dollar -, the immediate macroeconomic effects of the sudden economic liberalization, and the praise from key international actors -The Wall Street Journal talked about the "Argentine Miracle" (11/9/1992) - gave credibility to the government's discourse about Argentina finally getting on the right track to meet its purported "glorious destiny".

\section{THE IDEOLOGICAL LINK}

Among the Latin-Americanists who have dwelled on the issue of neopopulism, it is Weyland who has developed the most compelling analysis of its "unexpected affinities" with neoliberalism (Weyland, 1996, 1998, 1999). Weyland argues that the convergence of neoliberalism and neopopulism "is not simply a historical accident" (1996: 3). He defines the political core of populism as "a political strategy with three characteristics: a personal leader appeals to a heterogeneous mass of followers [...]; the leader reaches the followers in a seemingly direct, quasi-personal manner; [...) if the leader builds new organizations or revives earlier populist 
organizations, they remain personal vehicles with low levels of institutionalization" (1996: 5). Weyland's main argument is that "a purely political concept of populism opens up the possibility of finding populism and economic liberalism compatible" (1996: 6). He admits that the differences between neoliberalism and neopopulism are important, but he points out the fact that few studies have focused on their surprising and synergetic coexistence. Weyland puts forward the following thesis: "neopopulism and neoliberalism are both antiorganizational in their majoritarian or individualistic bent, respectively. In their conceptions of democracy, they stress counting numbers ('one citizen, one vote') as the main criterion and, in principle, refuse to recognize special weight, such as the economic clout of business groups" (1996: 9). These "inherent affinities" have allowed neoliberals and neopopulists to coincide in their targeted sources of mass support (unorganized and marginalized strata, particularly in the informal sector), their efforts to centralize power at the apex of the state (a top-down approach to expediently impose economic reforms), and their capacity to elicit popular support by promising to avert much greater damage and to revert large losses caused by hyperinflation (Weyland, 1998: 562). In this context, "neoliberal adjustment is acceptable and even attractive to neopopulist leaders, who can turn adversity to their advantage and gain widespread popular backing as saviors of their country" (Weyland, 1996: 18).

Weyland's approach to the compatibility between [neo]populism and [neo] liberalism is particularly interesting in that he explores, at a more profound level, their "shared visions and goals": "Both contemporary populism and liberalism see individuals, not groups, as the building blocks of economy and politics and advocate an unmediated relationship between individuals and the state" (1999: 381-2). This insight is crucial in the understanding of the neopopulist-neoliberal phenomenon. That is, there has to be an ideological link between the two approaches for them to function efficiently. They are far from being perfectly well-matched, but they cannot coexist solely on the basis of political strategy. The state must produce a sufficiently consistent and convincing representation of social change in order to legitimize its causes and effects. Even those who see the presidential rhetoric as purely deceiving, have to consider the fact that the president constructs his untruthful or misleading claims in a very careful and systematic way. He does not, as a superficial observation would suggest, say one thing and $d o$ a completely different one. The president has to put forward a meaningful connection between the nation's past, present, and future in order to elicit popular support. As the data of our research show, Menem delivers a coherent discourse which is nor just a repetition of old Peronist clichés, neither an account that is completely disconnected from reality. He actually speaks of the market as a key aspect of social life, he salutes globalization as an opportunity for economic development, and he articulates his reform project in terms of the national myth of "Great Argentina". In brief, Menem is not just a populist leader who distracts the masses with emotional rhetoric so as they do not "see" the full extent and consequences of his neoliberal economic policies. He actually calls attention to these policies (in broad and enthusiastic 
terms), by explaining that they are exactly what the country needs to "stand up", "take off", and "meet its destiny".

We argue that neoliberalism is not restricted to the economic realm, as the content of economic policy: neoliberalism is (1) a comprehensive conception of society and the individual, (2) distinct from classic liberalism, and (3) prone to develop populist tendencies. The neoliberal ideology can be characterized, in essence, as being based on an atomistic and fatalistic conception of society. It is atomistic because society is considered to be composed of discrete agents who seek to maximize their own gain, rather than equal partners sharing a set of fundamental civic rights, social entitlements and mutual obligations. In this view, collective identities and institutional mediations bear little relevance outside the individual's private life. Furthermore, the neoliberal ideology is fatalistic because it focuses on the achievement of a superior goal, the success of the country - measured in terms of total utility (e.g. the GNP) - as a contender in the globalized marketplace. That is to say, the richer the country gets, the better, regardless of distribution issues and procedural concerns. Instead of asserting the idea that a society is an open project, it presents the path as being "natural": it is "normal" that the state should not intervene, that borders must fall down in order to enhance international trade, that nations must submit to external competition in order to achieve internal welfare. Neoliberalism's atomistic and fatalistic dimensions are frequently hidden in a narrative that presents globalization as an unstoppable movement and dismisses nationalisms as atavistic ideologies that are bound to disappear. However, globalization does not presuppose the extinction of national identities. Actually, each country is conceived as a player within a global dynamics of production and consumption, and each country is expected to maximize its total utility in the exchange between "Us" and "Them". As in the populist conception of the "social whole", the individual destiny is presented as being linked to the national community's: every person who is apt to contribute and who does not take part in the collective effort is considered a liability in regard to the national economic performance. This discourse encompasses a moralistic call to all citizens: they ought to perform their duties to the country. In this sense, neoliberalism is both individualistic and majoritarian. While promoting "a fragmentation of civil society, a destructuring of institutional linkages, and an erosion of collective identities" (Roberts, 1995: 113), neoliberalism also promotes the faith in a spontaneous, empiric, non-mediated, empathic connection between the grassroots as a whole (the "real" and "profound" backbone of the nation) and leaders who praise the values of simplicity, directness, and common sense.

We will conclude by stressing our hypothesis that neoliberalism is actually inherently populist. Contrary to common wisdom, the neoliberal ideology is quite removed from traditional political liberalism. While political liberalism furthers a contractual and deontological conception of society, neoliberalism embraces the idea of an egoist and utilitarian individual, hardly concerned by issues of fairness and mutual obligation in the context of social cooperation (Rawls, 1971). This does not mean that neoliberalism does not address the question of collective goals; on 
the contrary, it espouses the key notion that the more "open", "productive", "competitive" society at large becomes, the better for the individual who is capable of seizing the opportunities for his or her personal advancement. ${ }^{8}$ The recent emergence of populist leaders in established democracies in Europe and North America is a reflection of this new ideological context (Betz and Immerfall, 1998). If populism was a rather specific trait of Latin American political culture, it would be hard to explain the - relative - success of leaders such a Joerg Heider in Austria and Preston Manning in Canada (Novaro, 1999). These populist leaders also address the "ordinary people", denounce the political elites and the special-interest groups, promote measures such as the flat-rate income tax, and evoke the most deeply rooted national myths to create a feeling of collective purpose in an extremely individualist setting. In Latin American countries such as Argentina, the conditions were there for the neoliberal ideology to have a uniquely strong hold: a cultural tradition which favors charismatic leadership, an extraordinary gap between the country's perceived potential and its actual accomplishments (accentuated by the traumatic experience of hyper-inflation), and a leader who was particularly gifted for conveying the populist message of the neoliberal ideology.

\section{REFERENCES}

ARMONY, Victor (2000) Représenter la nation: le discours présidentiel de la transition démocratique en Argentine (1983-1993), Montreal \& Paris: Balzac/Le Griot.

ARMONY, Victor and DUCHASTEL, Jules (1995) "Some Computer-Aided Heuristic Procedures for Political Discourse Analysis”, American Sociological Association Annual Meeting, Washington, D.C.

ARON, Raymond (1955) L'opium des intellectuels, Paris: Calmann-Lévy.

BECK, Ulrich (2000) What is Globalization?, Cambridge, Polity Press.

BETZ, Hans-Georg and IMMERFALL, Stefan (1998) The New Politics of the Right. Neo-Populist Parties and Movements in Established Democracies, New York: St. Martin's Press.

BOUDON, Raymond (1998) “Le phénomene idéologique: en marge d' une lecture de Pareto”, in Études sur les sociologues classiques, Paris: Presses Universitaires de France.

CALHOUN, Craig (1995). Critical Social Theory: Culture, History, and the Challenge of Difference, Cambridge, Mass.: Blackwell.

CANOVAN, Margaret (1999) “Trust the People! Populism and the Two Faces of Democracy”. Political Studies, vol. 47, $\mathrm{n}^{\circ} 1$.

DI TELLA, Torcuato (1965) "Populism and Reform in Latin America ", in Obstacles to Change in Latin America, Claudio Véliz (Ed.), London: Oxford University Press.

DIX, Robert (1985) “Populism: Authoritarian and Democratic”. Latin American Research Review, vol. $20, \mathrm{n}^{\circ} 2$.

GARCÍA CANCLINI, Néstor (2000) La globalización imaginada, Buenos Aires, Paidós.

\footnotetext{
${ }^{8}$ We have to keep in mind that globali zation involves both material processes and a change in consciousness and perception. For all its economic and technological causes and effects, globalization is also an "imagined" (García Canclini, 2000) and "reflexive" (Beck, 2000) development.
} 
KNIGHT, Alan (1998) "Populism and Neo-populism in Latin America, especially Mexico". Journal of Latin American Studies, $\mathrm{n}^{\circ} 30$.

NOVARO, Marcos (1999) "La década del menemismo", in Juan Carlos Torre, Marcos Novaro, Vicente Palermo and Isidoro Cheresky, Entre e/ abismo y la ilusión. Peronismo, democracia y mercado, Buenos Aires: Norma.

PHILIP, George (1998) "The new populism, presidentialism and market-orientated reform in Spanish South America". Government and Opposition, vo 1. 33, $\mathrm{n}^{\circ} 1$.

POCOCK, J. G. A. (1984). "Verbalizing a Political Act: Toward a Politics of Speech", in Michael Shapiro (Ed.), Language and Politics, Oxford: Basil Blackwell.

RAWLS, John (1971) A Theory of Justice, Cambridge: Harvard University Press.

ROBERTS, Kenneth M. (1995) "Neoliberalism and the transformation of populism in Latin America. The Peruvian case". World Politics, ${ }^{\circ} 48$.

WEYLAND, Kurt (1996) "Neopopulism and neoliberalism in Latin America: unexpected affinities". Studies in Comparative International Development, vol. 31, $\mathrm{n}^{\circ} 3$.

WEYLAND, Kurt (1998) "Swallowing the Bitter Pill: Sources of Popular Support for Neoliberal Reform in Latin America”. Comparative Political Studies, vol. 31, $\mathrm{n}^{\circ} 5$.

WEYLAND, Kurt (1999) “ Neoliberal populism in Latin America and eastern Europe”. Comparative Political Studies, vol. $31, \mathrm{n}^{\circ} 4$.

ZERMENO, Sergio (1993) '”Populismo' y ‘neopopulismo' en America Latina”. Revista Mexicana de Sociología, $\mathrm{n}^{\circ} 3$. 